\title{
IMPACT OF PROCESS REENGINEERING ON TECHNICAL EFFICIENCY OF THE HEALTH CARE PROVIDER
}

\author{
Blatnik Patricial, Tajnikar Maks², Tusak Matej ${ }^{3}$ \\ ${ }^{1}$ Faculty of Management, University of Primorska, Primorska, Slovenia \\ ${ }^{2}$ Faculty of Economics, University of Ljubljana, Ljubljana, Slovenia \\ ${ }^{3}$ Faculty of Sport, University of Ljubljana, Ljubljana, Slovenia
}

\section{UTICAJ PROCESA REINŽENJERINGA NA TEHNIČKU EFIKASNOST ZDRAVSTVENIH CENTARA}

\author{
Blatnik Patricial, Tajnikar Maks², Tušak Matej ${ }^{3}$ \\ ${ }^{1}$ Fakultet za menadžment, Univerzitet u Primorskoj, Primorska, Slovenija \\ ${ }^{2}$ Ekonomski fakultet, Univerzitet u Ljubljani, Ljubljana, Slovenija \\ ${ }^{3}$ Fakultet za sport, Univerzitet u Ljubljani, Ljubljana, Slovenija
}

\begin{abstract}
Objective. This article relates to the field which studies the impact of business process reengineering on technical efficiency. The reengineering method demonstrates its impact on the selected business process, the process of knee arthroscopy surgery. The impact of business process reengineering is studied on the example of a typical Slovenian general hospital.

Methods. In the first step, we demonstrate the selected business process in the existing situation, while the second step demonstrates the business process which could be reached in a potential situation. The demonstrated process is a basis for measuring the impact of business process reengineering on technical efficiency of a hospital.

Results. The results obtained show that the business process reengineering increases the technical efficiency of the selected general hospital. The volume of labour input in the existing situation was higher by $67.88 \%$, and the value fixed assets after business process reengineering decreased by $36.25 \%$, while the value of material costs before business process reengineering increased by $50.9 \%$.

Conclusion. This means that business process reengineering affects the hospital's technical efficiency, since the latter increases significantly if all the conditions of reengineering are met.
\end{abstract}

Keywords: hospitals; efficiency; economics; engineering; organization and administration.

\section{INTRODUCTION}

Health in the modern world is becoming one of the fundamental values which affects the behavior of an individual and also defines the strategy of the national policy in healthcare. The healthcare expenditure in the most developed countries is reaching almost $16 \%$ of its gross domestic product in some countries (1-3). Due to the financial crisis, the health sector, particularly hospitals, faces increasing difficulties (4). Health care service providers on one hand face pressures of health care service

\section{SAŽETAK}

Cilj. Ovaj članak se odnosi na oblast proučavanja uticaja poslovnih procesa reinženjeringa na tehničku efikasnost. Metod reinženjeringa pokazuje njegov uticaj na izabrani poslovni proces artroskopske operacije kolena. Uticaj poslovnih procesa reinženjeringa proučavan je na primeru tipične slovenačke opšte bolnice.

Metode. U prvom koraku pokazujemo izabrani proces $u$ postojećoj situaciji, dok drugi korak demonstrira renovirani poslovni proces, koji treba postići u potencijalnoj situaciji. Demonstrirani proces je osnova za merenje uticaja poslovnih procesa reinženjeringa na tehničku efikasnost u bolnici.

Rezultati. Dobijeni rezultati pokazuju da poslovni proces reinženjeringa povećava tehničku efikasnost izabrane opšte bolnice. Obim ulaznog rada u postojećoj situaciji bio je veći za $67,88 \%$ od potencijalne situacije, a potreban obim osnovnih sredstava nakon poslovnih procesa reinženjeringa smanjen je za 36,25\%, dok je vrednost materijalnih troškova veća za $50,9 \%$.

Zaključak. Poslovni proces reinženjeringa veoma utiče na tehničku efikasnost bolnice i znatno je povećava ako su ispunjeni svi uslovi reinženjeringa.

Ključne reči: bolnice; efikasnost; ekonomija; inžinjerstvo; organizacija i administracija.

payers, while on the other hand the number of patients is growing, mainly due to the aging population (5) and the increase in the number of chronic diseases (6-9). For these reasons, even health care began to look for solutions that increase efficiency and are already present in other economically oriented sectors. If Slovenia wants to develop an effective health system, it needs to tackle profound and radical changes. Inefficiency in health care, among other things, is primarily due to the fact that many processes are not performed optimally $(10,11)$. The biggest problems are reflected in the adoption of a patient, when ordering the patient to treatment, when patients are waiting to medical intervention, when doctors perform 
unnecessary additional medical tests, or while using various medicines and medical material. Greater efficiency would therefore be achieved by forming specific proposals for business process reengineering. Along with the expert criterion, (patient's wellbeing) the economic criterion is one of the key factors of business process reengineering within hospitals. The basic theoretical starting point of the article thus presents the theory of business process reengineering and microeconomic theory, in that part of the content that relates to the analysis of the efficiency of processes. There are several contemporary approaches, one of which is reengineering, which represent a thorough examination of business processes and their radical change that is triggered in order to achieve positive results in areas such as cost reduction, enhancement of quality, reducing delivery terms, etc. (12). Reengineering does not imply improvement of processes but rather their reformation. The dramatic nature of reengineering is indicated by significant changes in the mode of operation, as we are not talking about minor or gradual improvements. In reengineering it is necessary to achieve impressive progress, which is only possible by replacing the old method of work with a brand new one $(12,13)$. Reengineering has an impact on the efficiency of business processes. The impact of reengineering method therefore can be measured through the technical efficiency of health care providers. Health care services should be understood as goods and we should take into account that consumption of health care services influence health status (14). The production function in this case can be addressed through two steps. The definition of efficiency is linked to the production function of goods and service providers and to the definition of their final product or output (15). Healthcare services (m) can be defined as the final output produced by health care providers. In this case, the production function shows the relationship between healthcare services and factors of production or inputs by means of which an individual provider is able to provide healthcare services. Two inputs represent labour and capital, or more precisely, doctors, nurses and other health care professionals, available hospital beds, equipment and other inputs (15-17):

\section{$\boldsymbol{m}=\boldsymbol{f}$ (input)}

In this case, the provider of health care services is effective if it provides the maximum possible output of healthcare services within available resources (18). Producers could be defined as technically efficient in the production of a specific output when they produce a specific volume of output by employing the smallest possible volume of factors of production or inputs provided by the available technology (18-20). A characteristic feature of technically inefficient producer is that it could produce the given volume of output with smaller quantity of used inputs and that he or she could produce a greater amount of output with a given volume of inputs (21).

The issues of the presented article concern the field of studying the impact of business process reengineering on technical efficiency of a hospital. The technical efficiency of processes within the hospital was determined by comparing the economic indicators that defined the inputs and outputs of existing treatment methods of knee arthroscopy and then the potential treatment methods for of knee arthroscopy, which would be carried out at the department of day hospital.

Several aims of the research work were followed. The first aim of this paper was to create a model that enables the analysis of the existing business process of knee arthroscopy and its impact on a technical efficiency of the hospital. The second aim was to create a renovated business process of knee arthroscopy, made by reengineering method, and to explore its impact on the technical efficiency of the hospital. The final aim was to compare both existing and potential business processes of knee arthroscopy and to compare technical efficiency of both processes.

\section{MATERIAL AND METHODS}

We observed the existing business process model of knee arthroscopy in a General hospital Izola in Slovenia and we developed a new potential business process model of knee arthroscopy according to the main aim to optimize the process and reduce costs. To follow the aim of research a new original way of defining and measuring effects of business process reengineering was used as a new systematic identification of the effects of business process reengineering. The process was performed within the surgical department of a hospital. In terms of analysing technical efficiency an original method was applied to develop a process model. We compared existing business process model and new business process model after completed method of reengineering.

The original contribution shall also be the formation of a process model, which with interconnected constituent elements, allows to accurately define the extent of necessary and available inputs and volume of generated outputs at the level of individual organizational units of a general hospital. By observing the relationship between the physical volume of inputs and outputs, the process model can be used to assess the technical efficiency of a hospital in the existing and potential states. To realize the set objectives a combination of descriptive and analytical methods of studying was used. The distinction between the prevailing use of the first and the second is subordinate to the content structure. The content is divided into three sections: 
- In the first step, process modelling was used to show the existing situation in the business process referred to as "performance of knee arthroscopy surgery".

- In the second step, the process modelling was applied to implement a simulation of a potential situation after the reengineering of the "performance of knee arthroscopy surgery" business process.

- In the third step, the impact of business process reengineering was showed on technical efficiency of the selected hospital to identify the differences between the existing and a potential situation.

Reengineering is shown on one of business processes that are currently being carried out in one of the departments in General hospital Izola. This is a business process referred to as "performance of knee arthroscopy surgery", which is one of the most commonly performed procedures in surgical department in any general hospital, thereby posing a very interesting problem both for hospital management as well as for patients. "Performance of knee arthroscopy surgery" in the existing situation in the selected general hospital is carried out in a traditional hospital manner, which means that it is carried out within the framework of classical surgical department. As regards to the potential situation, the result of reengineering business process model "performance of knee arthroscopy surgery" is to be carried out by one of the models of day hospitals, which means surgeries are performed within an independent department of a day hospital and that this is a radical and a thorough reengineering of the existing business process.

Reengineering of that process is a good example for all processes which are now performed in classical surgical departments, but could be applied in day hospital, because they do not need prolonged hospitalization. Reengineering is also a very good and modern mechanism for all other business processes in a general hospital, but in those cases more multidisciplinary experts are needed and more creativity is demanded.

The analysis of technical efficiency requires information about the volumes of inputs and outputs of the general hospital in the process referred to as "performance of knee arthroscopy surgery". All data quoted are based on own calculations and conversations with employees in Slovenian general hospital Izola. In the first step, together with the managers of the hospital, doctors, nurses and other health and non-health workers we inventoried the performance of the existing process operation of knee arthroscopy. We defined the activity and properties of activities (e.g. take the patient) which were associated with the observed process. Discussed features of these activities included: a description (e.g. a nurse in the clinic admitted a patient and reviewed the documentation), time (e.g. 5 minutes), business rules (a nurse checked the documentation of the patient) and the inputs used in each section.
A description shows short description of activities, who is the performer of the activity, time reflects the time used to perform the activity, and a business rule is an exact description which describes, defines and controls structure, operation and strategy of the business. Inputs are the sum of input activities and resources which are needed to perform a specific health service. For easier understanding of the whole process we were present, together with the medical staff, at one surgery of knee arthroscopy which was performed in the General hospital Izola. In the working group the whole process was defined and described. The members of the working group consolidated opinions and their own understanding of the activities in the process, requested time for activities, the performer of the operations and all other important factors of the process.

General hospitals monitor outputs by using the methodology of diagnosis-related groups. Reengineering of "performance of knee arthroscopy surgery" business process can cause changes both on the volume of the generated outputs as well as the changes on the volume of the inputs consumed, but the analysis considers the fact that the number of patients treated in the general hospital for knee arthroscopy surgery does not change. Thus, we analyzed the impacts of business process reengineering on the volume of employed inputs in all activities involved in the business process "performance of knee arthroscopy surgery". In addition to the data on outputs, technical efficiency analysis also requires data on inputs used by the hospital in the existing process "performance of knee arthroscopy surgery". We used the following inputs for analysing technical efficiency: (a) work in the form of number of hours performed by a variety of personnel profiles, (b) capital in the form of property, equipment, and other tangible assets and (c) capital in the form of costs related to medicines, medical and other consumer material.

\section{RESULTS}

To show how the process "performance of knee arthroscopy surgery" was carried, we used the flowchart of the process.

\section{Analysis of the existing knee arthroscopy process in a general hospital}

The flowchart below was used to identify the opportunities for improving the business process and to eliminate the current problems. The business process referred to as the "performance of knee arthroscopy surgery" leads the patient, waiting for surgery, through several activities carried out in various departments of a general hospital. The flowchart, as shown in Figure 1, indicates that the "performance of knee arthroscopy surgery" business process includes the following 


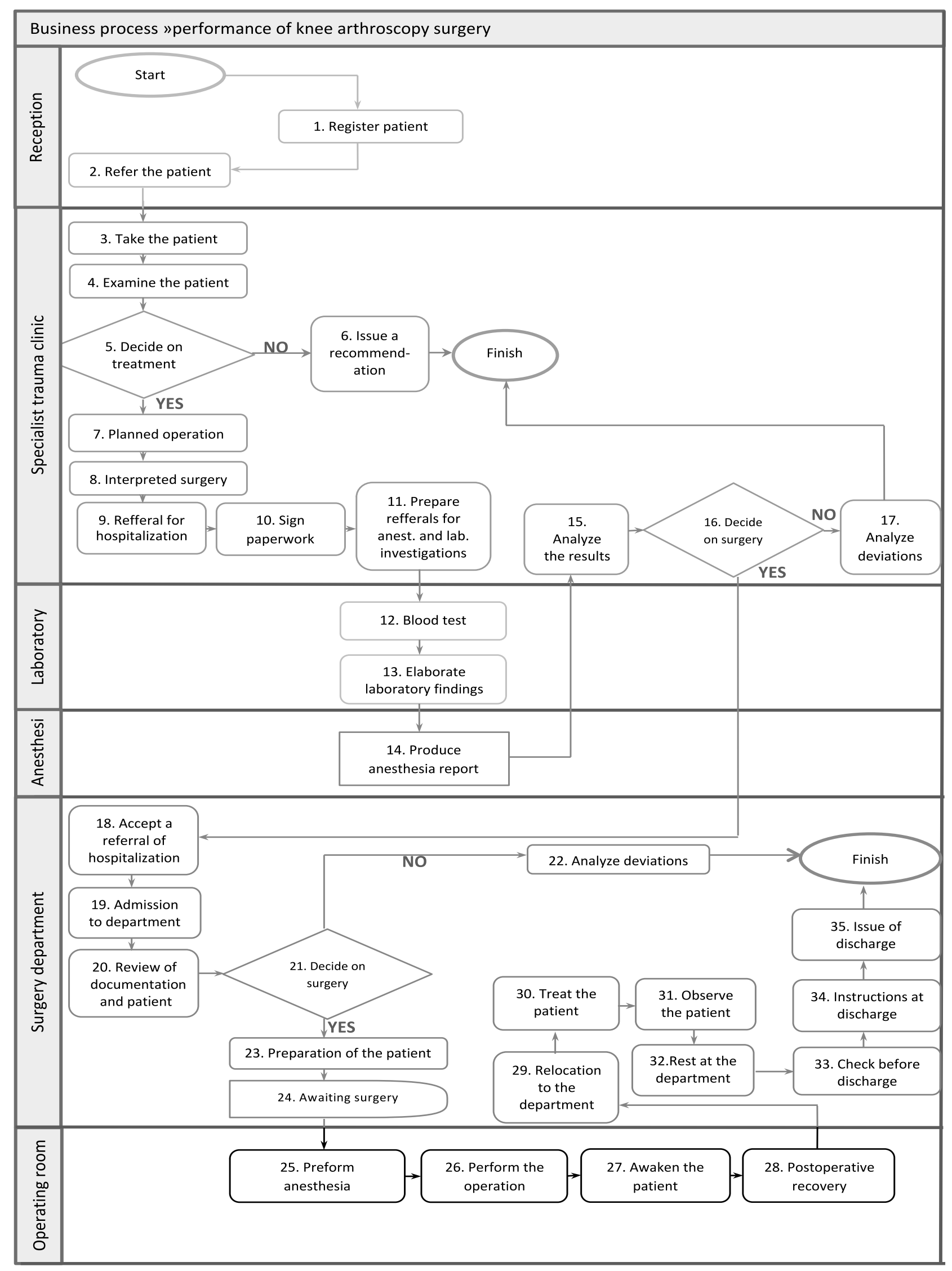

Figure 1. Diagram of the existing course of the »performance of knee arthroscopy surgery" process 
departments: admissions office, specialist trauma clinic, laboratory, anesthesia, surgical department and surgical block.

The process flowchart consists of six departments, whereby the majority of activities take place in the following departments; specialist trauma clinic, surgical department and surgical block. The admissions office, laboratory and anesthesia departments are minimally present in the process, as evident from the number of activities involved in the process.

The specialist trauma clinic department is involved in the business process referred to as the "implementation of the knee arthroscopy surgery" in implementation of twelve activities, which primarily relate to the first track of the patient's health status, as the department discontinues to participate in the process after issuing a recommendation to the patient or when the patient is referred to hospitalization.

Surgical department is significantly involved in the business process "implementation of the knee arthroscopy surgery", as it carries out more than half of the activities of this process. The patient is hospitalized in the department and prepared for the necessary surgery and this is also the place where the patient recovers after the surgery. This department also concludes with its participation in the business process after issuing discharge papers to the patient following the implemented hospitalization.

The operating room participates in the business process "implementation of the knee arthroscopy surgery" in implementing four activities: carrying out anesthesia, performing surgery, awakening the patient and postoperative recovery. This department is encountered by those patients for whom the doctor decides to proceed with surgery and who meet all the regulatory and prescribed criteria.

\section{Analysis of the renovated knee arthroscopy process in a general hospital}

Below we present a potential situation that is accessible upon the business process reengineering and would be implemented according to one of the day hospital models, which is referred to as the renovated business process "performance of knee arthroscopy surgery". The flowchart, as shown in Figure 2, indicates that the renovated "performance of knee arthroscopy surgery" business process would cover the following departments: admissions office, specialist trauma clinic, department of day hospital and surgical block of day hospital.

Diagram of the renovated process consists of four departments, where the majority of activities take place in the following departments: specialist trauma clinic, the department of the day hospital and surgical block of the day hospital. The admissions office department is minimally present in the process, as evident from the number of activities, which are active in the process.

The specialist trauma clinic department is involved in the renovated business process referred to as the "implementation of the knee arthroscopy surgery" in implementation of seven activities, which primarily relate to the first track of the patient's health status, as the department discontinues to participate in the process after issuing a recommendation to the patient or when the patient is referred to hospitalization. However, when compared to the existing situation the number of activities reduces significantly. Doctors and administrators are no longer burdened with writing referrals for a variety of tests, nor with analyzing the results and deciding on the implementation or cancellation of the surgery. All medical tests must be carried out at the primary healthcare. If patients do not come with all the necessary tests on the day of operation, the operation is not carried out.

The day hospital department is involved in the renovated business process "implementation of the knee arthroscopy surgery" in the biggest number of activities, and it is crucial in terms of business process reengineering. Similarly, as in the existing situation this department participates in carrying out fourteen activities, but this is a completely new and spatially separated department from the surgical department, which is only intended for the treatment of patients in a day hospital. The patient is examined in the department, prepared for the surgery, and in addition, the patient is also treated, observed, and allowed to rest within this department.

The surgical block department of a day hospital participates in the renovated business process "implementation of the knee arthroscopy surgery" in implementing three activities, which are: carrying out anesthesia, performing surgery and postoperative recovery. In this particular department the medical staff is no longer burdened with awakening of patients after surgery as these surgeries usually take place under local anesthesia, which means that patients are conscious once the surgery is completed. This department is encountered only by those patients who meet all the regulatory criteria for the performance of surgery.

\section{Technical efficiency in knee arthroscopy process}

Technical efficiency analysis requires information on the volume of outputs, which are available separately for different groups of activities carried out in a general hospital, which unfortunately does not apply to the volume of inputs. Data on the volume of inputs are available only at the level of a hospital as a whole; therefore, these data are assessed through interviews with employees in one of the Slovenian general hospitals. 


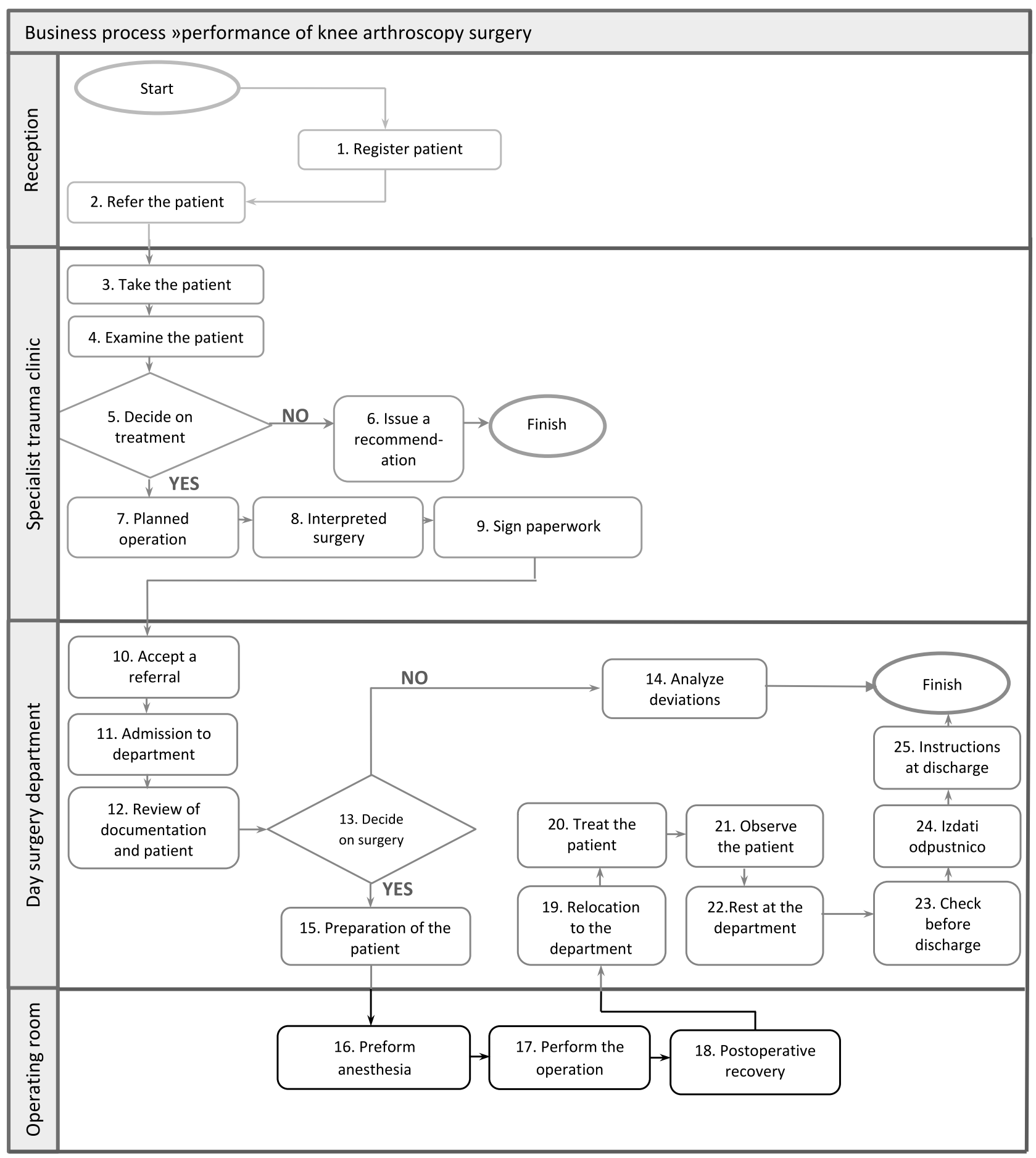

Figure 2. Diagram of the renovated course of the process "performance of knee arthroscopy surgery"

Matrix 1 shows results of the number of activities and time spent by the employees in a particular department. Data refer to the existing situation in the implementation of a single knee arthroscopy surgery. The first result (1) in this content set reveals the code of the personnel profile. In our case, we divided employees into nine categories, as follows: 1 - non-health workers, 2 - nurses, 3 - specialist surgeons, 4 - laboratory technicians, 5 -anesthesiologists,
6 - registered nurses, 7 - other medical staff, 8 - surgical instrumentalists, 9 - anesthetic technicians.

The second result (2) indicates a department in which individual process activities take place. The existing process "implementation of knee arthroscopy surgery" is carried out in six different departments: 1 - admissions office, 2 specialist trauma clinic, 3 - laboratory, 4 - anesthesiology clinic, 5 - surgery department, 6 - operating room. 


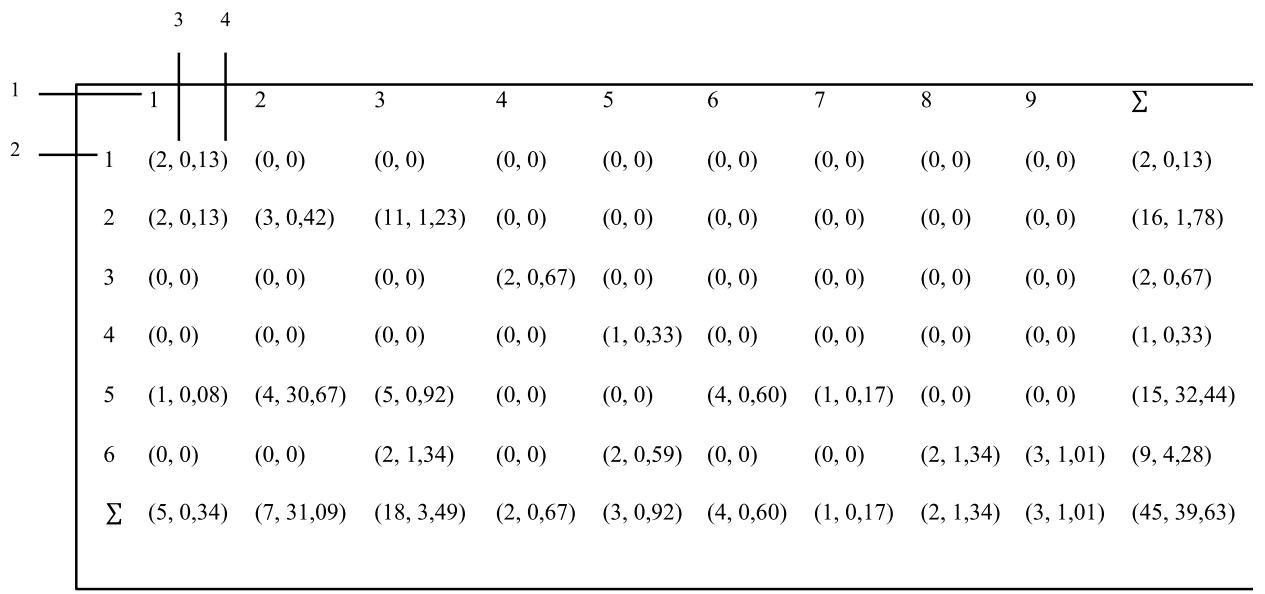

Matrix 1. The number of activities and time spent by the employees in existing situation

The third result (3) shows the number of activities performed by an individual personnel profile in a particular department. The fourth result (4) shows the actual working time expressed in hours for each type of employees in a particular department.

In the existing process of the "implementation of knee arthroscopy surgery" non-health workers, which include administrators, participate in five activities (register patient, refer the patient, referral for hospitalization, prepare referrals for anesthesia and laboratory investigations, accept a referral of hospitalization), nurses in seven activities (take the patient, planned operation, analyze deviations, preparation of the patient, relocation to the department, treat the patient, observe the patient), specialist surgeons in sixteen activities (examine the patient, decide on the treatment, issue a recommendation, plan operation, interpret surgery, refer for hospitalization, sign paperwork, prepare referrals for anesthesiology and laboratory investigation analyze the results, decide on surgery, analyze deviations, review of documentation and patient, decide on surgery, analyze deviations, perform the operation, check before discharges), laboratory technicians in two activities (blood test, elaborate laboratory findings), anesthesiologists in three activities (produce anesthesia report, preform anesthesia, awake the patient), registered nurses in four activities (admission to department, review of documentation and patient, analyze deviations, instructions at discharge), other medical staff, which includes a medic, in one activity (relocation to the department), surgical instrumentalists in one activity (preform the operation) and anesthetic technicians in three activities (preform anesthesia, awaken the patient, postoperative recovery). Based on the flowchart of the existing process, we also evaluated the time of performing individual activities in a specific department. To perform all their activities administrators need a total of 0.34 hours, nurses 31.09 hours, specialist surgeons 3.49 hours, laboratory technicians 0.67 hours, anesthesiologists 0.92 hours, registered nurses 0.60 hours, medics 0.17 hours, surgical instrumentalists 1.34 hours and anesthetic technicians 1.01 hours.

Matrix 2 shows results on the number of activities and time spent by employees in a particular department. Data refer to the potential situation, which in the renovated process relates to "implementation of the knee arthroscopy surgery". The first result (1) in this content set reveals the code of the personnel profile. In our case, we divided employees into six categories, as follows: 1 - non-health workers, 2 - nurses, 3 - specialist surgeons, 6 - registered nurses, 8 - surgical instrumentalists, 9 - anesthetic technicians.

The second result (2) indicates a department in which individual process activities take place. Renovated process "implementation of knee arthroscopy surgery" is carried

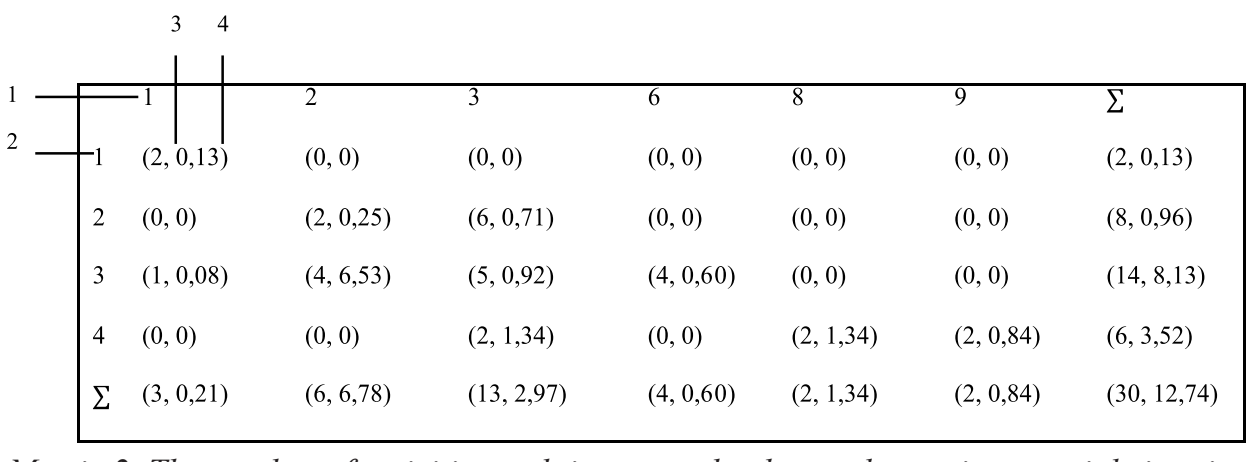

Matrix 2. The number of activities and time spent by the employees in potential situation 
out in four different departments: 1 - admissions office, 2 - specialist trauma clinic, 3 - day hospital department, 4 operating room.

The third result (3) shows the number of activities performed by an individual personnel profile in a particular department. The fourth result (4) shows the actual working time expressed in hours for each type of employees in a particular department.

Following the reengineering of the business process, the number of activities and the actual working time that employees spent would change significantly. In addition, certain profile groups would no longer be necessary, among them anesthesiologists, laboratory technicians and other medical staff. Thus, non-health workers with nonmedical education, nurses, specialist surgeons, registered nurses, surgical instrumentalists and anesthetic technicians participate in the renovated process referred to as the "implementation of the knee arthroscopy surgery". For the implementation of the renovated process administrators require 0.21 hours, nurses a total of 6.78 hours, specialist surgeons 2.97 hours, registered nurses 0.60 hours, surgical instrumentalists 1.33 hours and anesthetic technicians 0.84 hours.

The volume of capital input is defined as the value of property, equipment and other tangible assets as well as the value of medicines, medical and other material. In the business process "implementation of the knee arthroscopy surgery" we noted allocations of other elements of the observed hospital. We considered only those elements of the capital, which were directly affected by the business process reengineering.

The aim of the value of assets is to express the quantity or the volume of capital input in the business process "implementation of the knee arthroscopy surgery", therefore we used data on the cost of fixed assets in this particular part of our paper. Using data on the cost of fixed assets allows us to ignore the differences in write-off ratios and utilization of fixed assets. These are values of fixed assets, which are necessary for the implementation of the knee arthroscopy surgery. This does not take into account the write-off rates of fixed assets and their utilization.

Matrix 3 shows result on the number of activities and the value of fixed assets per individual departments within the existing process of the "implementation of the knee arthroscopy surgery". The first result (1) in this content set reveals the code of fixed assets that were divided into two groups. The first group includes fixed assets in form of property, and the second group includes fixed assets in form of equipment and other tangible assets.

The second result (2) indicates a department in which individual process activities take place. The existing process "implementation of knee arthroscopy surgery" is carried out in six different departments, as already defined in Matrix 1.

The third result (3) shows the number of activities, which include certain fixed assets. The fourth result (4) is the value of fixed assets denominated in Euro according to the illustrated department.

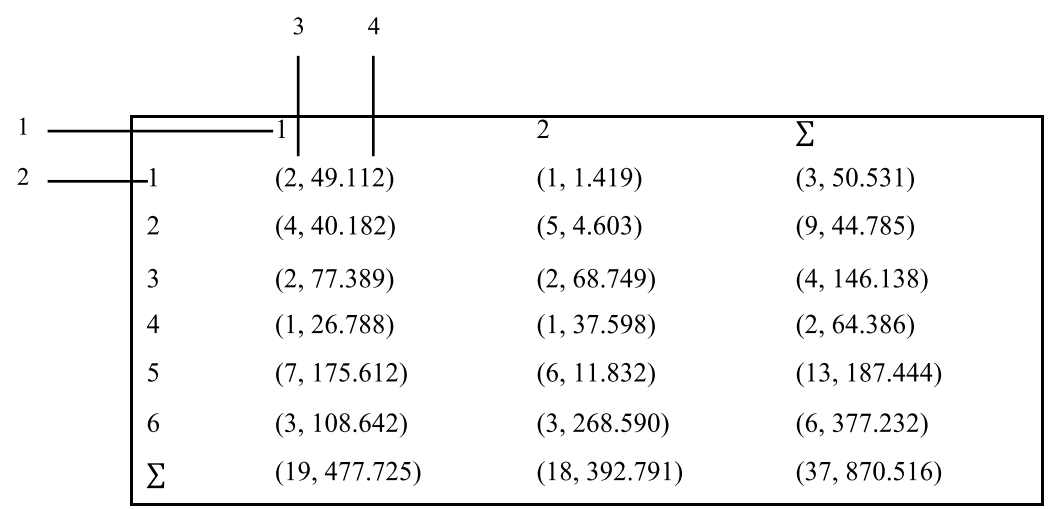

Matrix 3. The number of activities and the value of fixed assets per individual departments in existing situation

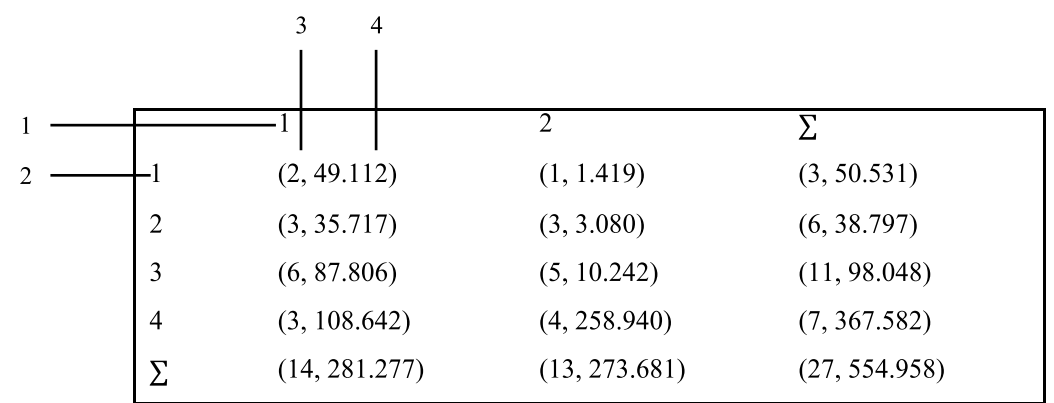

Matrix 4. The number of activities and the value of fixed assets per individual departments in the potential situation 
Matrix 4 shows results on the number of activities and the value of fixed assets per individual departments within the renovated process of the "implementation of the knee arthroscopy surgery". The first result (1) in this content set reveals the code of fixed assets. Fixed assets were divided into two groups, as already defined in Matrix 3.

The second result (2) indicates the department in which individual process activities take place. The renovated process "implementation of knee arthroscopy surgery" is carried out in four different departments, as already defined in Matrix 2.

The third result (3) shows the number of activities, in which their implementation requires specific fixed assets. The fourth result (4) is the value of fixed assets denominated in Euro according to the illustrated department.

The value of material costs is used to express the remainder of the volume of capital input in the business process "implementation of the knee arthroscopy surgery". In this part we used the data on the cost of medicines, medical and other consumer material. The illustrated material costs relate to the implementation of a single knee arthroscopy surgery.

Matrix 5 thus shows results on the number of activities and the value of material costs per individual departments within the existing process "implementation of the knee arthroscopy surgery". The first result (1) in this content set reveals the code of material costs. Material costs were divided into three groups, as follows: 1 - consumer material, 2 - medical material, 3 - medicines. The third result (3) shows the number of activities, in which their implementation requires specific material costs. The fourth result (4) is the value of material costs denominated in Euro according to the illustrated department.

Matrix 6 shows results of the number of activities and the value of material costs per individual departments within the renovated process of the "implementation of the knee arthroscopy surgery". The first result (1) in this content set reveals the code of material costs. Material costs were divided into three groups, as already defined in Matrix 5.

The second result (2) indicates the department in which individual process activities take place. The renovated process "implementation of knee arthroscopy surgery" is carried out in four different departments, as already defined in Matrix 2.

The third result (3) shows the number of activities that require specific material costs to be implemented. The fourth result (4) is the value of material costs denominated in Euro according to the illustrated department.

A significant change in the value of material costs is due to the suspension of certain activities. In case of business process reengineering we would thus avoid the preparation of referral for hospitalization and preparation of referral for laboratory tests and anaesthesiological examination. We would no longer have to test the blood, and to prepare laboratory and anaesthesia result. Consequently, this means that we would also avoid analysing the results, deciding on surgery, and analysing

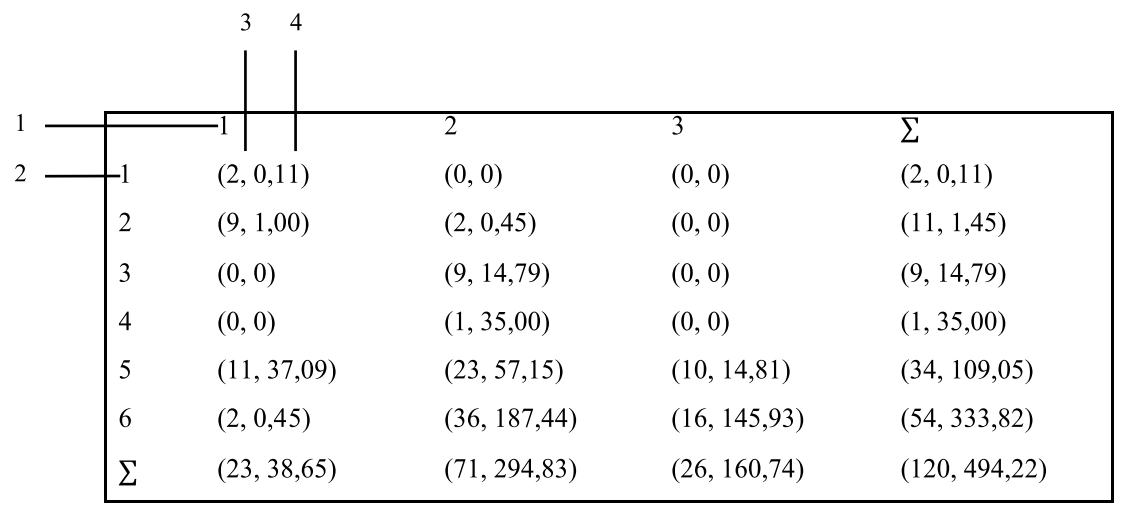

Matrix 5. The number of activities and the value of material costs per individual departments in the existing situation

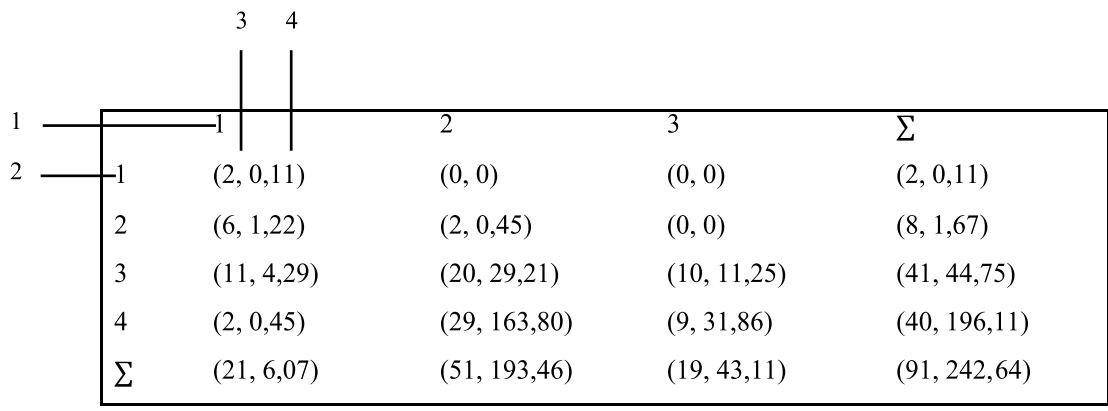

Matrix 6. The number of activities and the value of material costs per individual departments in the potential situation 
Table 1. Technical efficiency of a general hospital in the existing and potential situations

\begin{tabular}{|l|r|r|}
\hline \multicolumn{1}{|c|}{ Inputs } & $\begin{array}{c}\text { Volume of inputs in the } \\
\text { existing situation }\end{array}$ & $\begin{array}{c}\text { Volume of inputs in the } \\
\text { potential situation }\end{array}$ \\
\hline Volume of work in hours input & 39.63 & 12.73 \\
\hline Fixed assets value in EUR & $870,516.00$ & $554,958.00$ \\
\hline Material costs value in EUR & 494.22 & 242.64 \\
\hline Total volume of labour in hours input & 39.64 & 12.73 \\
\hline Total volume of capital in EUR input & $871,010.22$ & $555,200.64$ \\
\hline
\end{tabular}

possible deviations. A patient in a hospital would no longer have to wait for the performance of surgery, would be conscious after the procedure, which means avoiding the activity of awakening the patient. The value of material costs in planning the surgery, admission to the department, implementation of anaesthesia, awakening the patient, patient observation and recovery in the department would also change due to the different organization of work.

To illustrate the differences between the technical efficiency of a general hospital in the existing situation and in the potential situation we are hereby presenting a table showing the differences in the extent of labour input and capital. Their value is a measure of technical efficiency, based on which we can establish the impact of business process reengineering on the technical efficiency of the general hospital.

Table 1 and the calculated changes relate only to those elements of labour and capital, which are under direct impact of business process reengineering. Inputs represent the volume of labour input and capital in the performance of a single knee arthroscopy surgery.

\section{DISCUSSION}

Reengineering causes changes in efficiency of the hospital, which is reflected in several improvements and savings at the level of a hospital. The research showed that the implementation of the renewed business process can achieve dramatic changes that contribute to greater efficiency of the process "performance of knee arthroscopy surgery". Several other researches in the field of reengineering also mention similar findings (22-24). The comparison of existing and renovated process showed some changes which indicated advantages of the reengineered process. Unlike the existing situation, we can see that after business process reengineering the number of activities in the "performance of knee arthroscopy surgery" business process would be reduced. Renovated process could thus cover only twenty-five activities, while there are thirty-five activities implemented in the existing situation. Many other authors also recognize healthcarerelated benefits of reengineering (25-27).
Business process would still lead a patient, who is awaiting surgery, through a set of activities that would be implemented in different departments of a general hospital; however, some key activities would be transferred into implementation by the primary level of health care. In addition, the majority of activities would be carried out in a newly-established department of a day hospital, which would be kept spatially separated from the surgical department. The usefulness of such a regime has been noted in almost all research in the field of day care $(28-33)$. In the renovated process laboratory and anesthesia departments would be excluded, compared to the existing process. In the renovated process the patient would have the obligation to undergo all laboratory and anesthetic tests at the primary level of health care beforehand. The same is also proposed by other authors $(28,29)$. On the day of the scheduled surgery, the patient would thus come and bring along all the necessary results and a valid referral from a general practitioner. The substantial change would also be in other activities related to time, when patient needs to wait for the next step. This is also confirmed by other studies $(30,31)$. The patient would have an appointment on a specific day and the operating room of the day hospital would thus be reserved at a specific time period. The patient would thus avoid unnecessary waiting for the surgical block to become available, because the operation room of the day hospital would be intended only for patients who are scheduled for surgeries in a day hospital. Such a regime of the activities within this process is also proposed by other authors (32, 33 ). In addition, patients would spend significantly less time in the hospital, as they would be discharged on the same day and would thus avoid being hospitalized overnight. Patients could rest at home rather than in hospital. Consequently, medical staff could also spend less time monitoring the patients. The same conclusions have been made in several other studies (28-33). This way, patients would not be required to needlessly wait for the morning rounds and their discharge.

The reengineering impact can also be recognized through technical efficiency. In the existing situation, the volume of labour input for a particular surgery totals 39.63 hours, and in the potential situation, the aforementioned 
volume of labour input would be equal to 12.73 hours. Labour input would thus decrease by $67.88 \%$. The value of tangible assets in the existing process "performance of knee arthroscopy surgery" totals 870,516 EUR, while in the renovated process this amount would be equal to 554,958 EUR. The category would thus decrease by 63.75 $\%$. The value of material costs in the existing situation of knee arthroscopy surgery totals 494.22 EUR, while in the potential situation this value would be equal to 242.64 EUR. Before the business process reengineering the material cost value is higher by $50.9 \%$. The total volume of labour input of the existing business process amount 39.64 hours, while the renovated business process amount 12.73 hours. The amount of total capital input for the existing situation is equivalent to $871,010.22$ Euro, while $555,200.64$ Euro for the potential situation. This means that the total volume of labour input would be reduced by $67.88 \%$ and the total volume of capital input would be reduced by $36.26 \%$. This is in accordance with several cost studies which estimated an average cost savings of $17.6 \%$ to $57.6 \%$ for day hospital procedures relative to similar procedures performed in hospital (34-37). All these results suggest that in the case of business process reengineering technical efficiency of a hospital increases. Reengineering of the "performance of knee arthroscopy surgery" business process thus affects the technical efficiency of a general hospital.

\section{CONCLUSIONS}

Technical efficiency of the existing process of knee arthroscopy was compared with technical efficiency of the potential process of knee arthroscopy in General hospital Izola. The results confirm the important impact of the business process reengineering on technical efficiency. When analyzing technical efficiency data were calculated on the quantity volume of inputs for a single knee arthroscopy surgery prior to and after the business process reengineering. For technical efficiency, we calculated the volume of labour input and the volume of capital input. The volume of labour input in the existing situation was higher by $67.88 \%$, and the value of fixed assets after business process reengineering decreased by $36,25 \%$, and the value of material costs before business process reengineering increased by $50.9 \%$. The total volume of labour input in the potential situation thus decreased by $67.88 \%$, and the total volume of capital input decreased by $36.26 \%$. All these results therefore suggest that business process reengineering does affect the hospital's technical efficiency and would increase significantly if all the conditions of reengineering were met.

Certain limitations should be mentioned concerning our study. Our data were adapted to the specific situation of General hospital Izola. Several factors could differ for specific services. In specific hospitals, different factors can differ such as price of labor, price of capital, space availability etc. and especially in other healthcare systems which can be defined by specific rules and obligations. But the idea of reengineering remains the same and the results prove the benefit and possibility of optimization of certain process through the process of reengineering.

\section{REFERENCES}

1. OECD Health Data 2016. Paris: Organisation for Economic Co-operation and Development: 2016. http://stats.oecd.org/Index.aspx?DataSetCode=SHA

2. Jakovljevic M, Potapchik E, Popovich L, Barik D, Getzen T. Evolving health expenditure landscape of the BRICS nations and projections to 2025. Health Econ 2016. (doi: 10.1002/hec.3406).

3. Jakovljevic M, Getzen TE. Growth of global health spending share in low and middle income countries. Front Pharmacol 2016; 7: 21. (doi: 10.3389/fphar.2016.00021)

4. Jakovljevic M, Souliotis K. Pharmaceutical expenditure changes in Serbia and Greece during the global economic recession. SEEJPH 2016; Apr 06. SEEJPH 2016; 5. (doi: 10.4119/UNIBI/SEEJPH2016-101)

5. Ogura S, Jakovljevic M. Health financing constrained by population aging - an opportunity to learn from Japanese experience. Ser J Exp Clin Res 2014; 15: 175-81.

6. Wang H, Naghavi M, Allen C, et al. Global, regional, and national life expectancy, all-cause mortality, and cause-specific mortality for 249 causes of death, 1980-2015: a systematic analysis for the Global Burden of Disease Study 2015. Lancet 2016; 388: 1459-544.

7. Vos T, Allen C, Arora M, et al. Global, regional, and national incidence, prevalence, and years lived with disability for 310 diseases and injuries, 1990-2015: a systematic analysis for the Global Burden of Disease Study 2015. The Lancet 2016; 388: 1545-602.

8. Ba Sorenson C, Drummond M, Bhuiyan Khan B. Medical technology as a key driver of rising health expenditure: disentangling the relationship. ClinicoEconomics and Outcomes Research: CEOR 2013; 5: 223-34.

9. Eaddy MT, Cook CL, O’Day K, et al. How Patient Cost-Sharing Trends Affect Adherence and Outcomes: A Literature Review. Pharmacy and Therapeutics 2012; 37: 45-55.

10. Hofmarcher MM, Oxley H, Rusticelli E. Improved Health System Performance Through Better Care Coordination. OECD Health Working Paper No 30. Paris: The Organisation for Economic Co-operation and Development: 2007. 
11. Jakovljevic MB. Resource allocation strategies in Southeastern European health policy. Eur J Health Econ 2013; 14: 153-9.

12. Hammer M, Champy J. Reengineering the corporation: a manifesto for business revolution. New York: Harper Business; 1993.

13. Hindle T. The economist guide to management ideas and gurus. London: The Economist; 2012.

14. Grossman M. On the concept of health capital and the demand for health. Journal of Political Economy 1972; 80: 223-55.

15. Feldstein PJ. Health care economics. 5th ed. Clifton Park: Thomson - Delmar Learning, 2002.

16. Došenović P. Cost efficiency of basic health care providers in Slovenia. Ljubljana: Faculty of Economics, 2004.

17. Došenović Bonča P. Innovations as determinants of hospital efficiency and performance: the case of Slovenia. Ljubljana: Faculty of Economics, 2010.

18. Coelli TJ, Prasada Rao DS, O'Donnell CJ, Battese GE. An introduction to efficiency and productivity analysis. New York: Springer, 2005.

19. Fried HO, K Lovell CA, Schmidt SS. The measurement of productive efficiency and productivity change. Oxford: Oxford University Press, 2008.

20. Greene WH. The econometric approach to efficiency analysis. In Fried HO, K Lovell CA, Schmidt SS, eds. The measurement of productive efficiency and productivity growth. Oxford: Oxford University Press, 2008: 92-250.

21. Daraio C, Simar L. Advanced robust and nonparametric methods in efficiency analysis. Methodology and applications. New York: Springer, 2007.

22. Carmichael BD. Business process reengineering: a remedy for health care. Healthc Manage Forum 1994; 7: 44-50.

23. Boland $P$. The role of reengineering in health care delivery. Manag Care Q 1996; 4: 1-11.

24. Anthony D, Chetty VK, Kartha A, et al. Reengineering the hospital discharge: an example of a multifaceted process evaluation. In: Henriksen K, Battles JB, Marks ES, eds. Advances in patient safety: from research to implementation: Rockville: Agency for Healthcare Research and Quality, 2005.

25. Pillar B, Jarjoura D. Assessing the impact of reengineering on nursing. J Nurs Adm 1999; 29: 57-64.
26. Pardridge WM1, Boado RJ. Reengineering biopharmaceuticals for targeted delivery across the blood-brain barrier. Methods Enzymol 2012; 503: 26992.

27. Bakshi SM. Business process re-engineering a cardiology department. World Hosp Health Serv 2014; 50: 40-5.

28. Fincke BG, Gaehde SA, Rubins HB. The medical day hospital. A new concept in ambulatory medical education. Arch Intern Med 1990; 150: 533-6.

29. Marshall M, Crowther R, Almaraz-Serrano AM, Tyrer P. Day hospital versus out-patient care for psychiatric disorders. Cochrane Database Syst Rev 2001; 3: CD003240.

30. Priebe S, Jones G, McCabe R, et al. Effectiveness and costs of acute day hospital treatment compared with conventional in-patient care: randomised controlled trial. Br J Psychiatry 2006; 188: 243-9.

31. Burch S, Longbottom J, McKay M, Borland C, Prevost T. A randomized controlled trial of day hospital and day centre therapy. Clin Rehabil 1999; 13: 105-12.

32. Abbate-Daga G, Gramaglia C, Preda S, Comba E, Brustolin A, Fassino S. Day hospital programmes for eating disorders: a review of the similarities, differences and goals. Eat Weight Disord. 2009; 14: e31-41.

33. Petermans J, Velghe A, Gillain D, Boman X, Van Den Noortgate N. Geriatric day hospital: what evidence? A systematic review. Geriatr Psychol Neuropsychiatr Vieil 2011; 9: 295-303.

34. Kao JT, Giangarra CE, Singer G, Martin S. A comparison of outpatient and inpatient anterior cruciate ligament reconstruction surgery. Arthroscopy 1995; 11: 151-6.

35. Bertin KC. Minimally invasive outpatient total hip arthroplasty: a financial analysis. Clin Orthop Relat Res 2005; 435: 154-63.

36. Lovald ST, Ong KL, Malkani AL, et al. Complications, mortality, and costs for outpatient and short-stay total knee arthro-plasty patients in comparison to standard-stay patients. J Arthroplasty 2014; 29: 510-5.

37. Aynardi M, Post Z, Ong A, Orozco F, Sukin DC. Outpatient surgery as a means of cost reduction in total hip arthroplasty: a case-control study. HSS J 2014; 10 : 252-5. 